\title{
Disability in the Margin of Loneliness Research and Policy
}

\author{
Antti Teittinen* \\ Department of Research and Development, Finnish Association on Intellectual and Developmental Disabilities, Finland \\ *Corresponding author: Antti Teittinen, Department of Research and Development, Finnish Association on Intellectual and \\ Developmental Disabilities, Finland
}

Received: 兴June 07, 2019

Published: 䟧June 12, 2019

\begin{abstract}
Loneliness is a key deficiency in well-being and health for the people of our time and, as a result, a major social policy issue. In Finland, the link between loneliness, poor health, ability to work and recovery from different lifestyles has been noticed in surveys of both population levels and individual groups, such as mental health rehabilitators, homeless people, and bread-line customers. However, the loneliness of people with disabilities has not been studied in Finnish society. The aim of the UN Convention on the Rights of Persons with Disabilities is to include people with disabilities and other marginalized groups of disability in national health, lifestyle and similar research. The samples selected for research are usually removed, for example, by persons in institutions or service homes. The living conditions, quality of life and many other issues of the various groups of injuries have been studied primarily - and almost exclusively - within these groups and even using 'disability-specific' indicators, making comparison with the rest of the population impossible. It is also worrying that people with disabilities do not have the opportunity to influence their position in the current change in the service structure, including housing and everyday life. For example, residents who move from institutions have not been listened to in the abolition of institutional care. It can be rightly asked whether people with disabilities will be thrown away and lobbied when major structural reforms are underway.
\end{abstract}

\section{Introduction}

Disability information and practical solutions based on it for the everyday life of people with disabilities are deficient and there is a risk of marginalization and alienation of people with disabilities. At worst, it is possible to talk about a cycle of negativity, where abandonment, marginalization and alienation can be related to psychoactive substance use, crimes or suicide. The fight against loneliness is the prevention of such a thread. But how and why should we study the loneliness of disabled people? Research on the subject is scattered and scarce. Material focused exclusively on loneliness has not been collected by people with disabilities. Existing studies have focused on materials where loneliness has been touched in one way or another. When studying the loneliness of people with disabilities, it is worthwhile to consider at least the following: disability itself does not tell or explain anything, and disabled people are either a homogeneous group. In the 2013 Regional Health and Welfare Questionnaire (ATH), the question of loneliness has been asked by "Do you feel lonely?". The answers have been "Never", "Very rarely", "Sometimes", "Quite often" or "Continuously". A large fifth (22\%) of the needs of disabled people ( $N=1044$ ) felt quite often or constantly lonely when about one in ten $(9 \%)$ felt alone as the lonely ones [1]. In a survey conducted by [2], 39\% of people with disabilities reported being lonely.

\section{Conclusion}

The knowledge base on the loneliness of people with disabilities is very fragmented, but on the basis of individual results, people with disabilities are more lonely than other people. Written material gathered in 2003 explains the factors behind the loneliness of disabled people. In the light of the material, the loneliness of people with disabilities appears to be experiences of the other and the outside: a much deeper experience than just a lack of people. Rather, it is represented as a lack of relevance [3,4]. As a societal issue about the loneliness of people with disabilities, not only factors related to the individual's social standing, but also the habitat factors that bring about and maintain the loneliness experienced by disabled people, but also can contribute to inclusion and lasting contact with other people can be presented. Politically, in particular, the body issues and structures and values of the society determine how people with disabilities can participate in various activities such as independent living, work and social relationships; to determine her/his own life; make free choices according to one's wishes and abilities; and live in an accessible environment, if necessary with the help of special services. These segments of social policy have also been highlighted as key areas 
in the Finnish Disability Policy Programmed. Such policy papers do not in themselves oblige or act as a clear justification for disability policy or individual empowerment but reveal that the fight against loneliness seems to have a deep gap between ideologies and practices that should not be ignored.

\section{References}

1. Teittinen, Antti Ja Vesala, Hannu (2015) Vammaispalveluja tarvinneiden taloudellinen tilanne ja osallistuminen-ATH-tutkimuksen tuloksia. Teoksessa Murto, Jukka,
Oona Pentala, Satu Helakorpi, Risto Kaikkonen (toim.) Yksinäisyys ja osallistuminen, ATH-tutkimuksen tuloksia, Järjestökentän tutkimusohjelma. THL Työpapereita 25: 25-31.

2. Heini, Annina (2013) Vammaisten henkilöiden terveyskäyttäytyminen ja koettu hyvinvointi. Sosiaalipolitiikan pro gradu tutkielma. Turun yliopisto.

3. Rosedale Mary (2007) Loneliness: An exploration of Meaning. Journal of the American Psyhiatric Nurses Association 13(4): 201-209.

4. Stuewe Portnoff Greg (1988) Loneliness: Lost in the landscape of meaning. The Journal of Psychology: Interdisciplinary and Applied 122(6): 545-555.

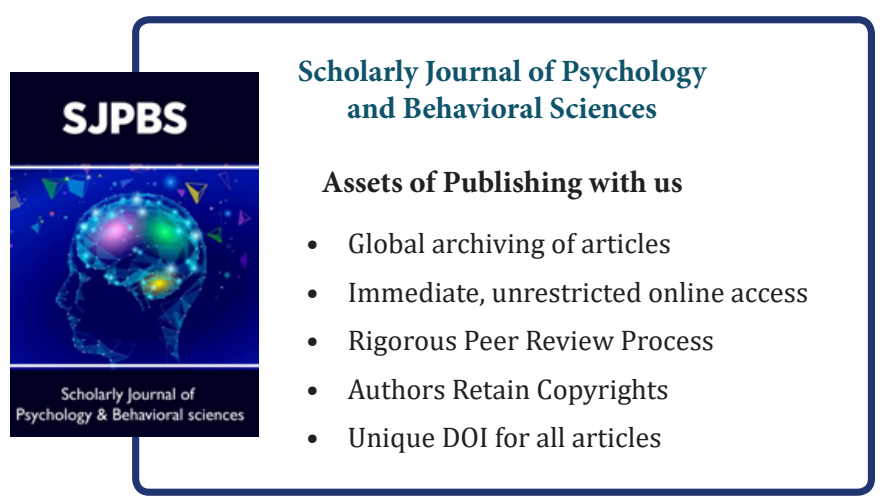

